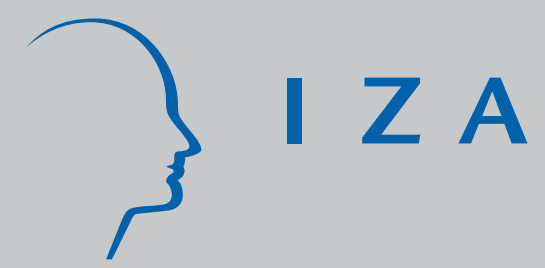

IZA DP No. 8983

The Effects of a High School Curriculum Reform on University Enrollment and the Choice of College Major

Katja Görlitz

Christina Gravert

April 2015 


\title{
The Effects of a High School Curriculum Reform on University Enrollment and the Choice of College Major
}

\author{
Katja Görlitz \\ FU Berlin, IZA and RWI Essen \\ Christina Gravert \\ University of Gothenburg
}

Discussion Paper No. 8983

April 2015

IZA

P.O. Box 7240

53072 Bonn

Germany

Phone: +49-228-3894-0

Fax: +49-228-3894-180

E-mail: iza@iza.org

Any opinions expressed here are those of the author(s) and not those of IZA. Research published in this series may include views on policy, but the institute itself takes no institutional policy positions. The IZA research network is committed to the IZA Guiding Principles of Research Integrity.

The Institute for the Study of Labor (IZA) in Bonn is a local and virtual international research center and a place of communication between science, politics and business. IZA is an independent nonprofit organization supported by Deutsche Post Foundation. The center is associated with the University of Bonn and offers a stimulating research environment through its international network, workshops and conferences, data service, project support, research visits and doctoral program. IZA engages in (i) original and internationally competitive research in all fields of labor economics, (ii) development of policy concepts, and (iii) dissemination of research results and concepts to the interested public.

IZA Discussion Papers often represent preliminary work and are circulated to encourage discussion. Citation of such a paper should account for its provisional character. A revised version may be available directly from the author. 


\section{ABSTRACT}

\section{The Effects of a High School Curriculum Reform on University Enrollment and the Choice of College Major ${ }^{*}$}

This paper evaluates the effects of a high school curriculum reform on students' probability to enroll at university and to choose Science, Technology, Engineering or Mathematics (STEM) as college major. The reform that was introduced in one German state increased the degree of difficulty to graduate from high school by increasing the mandatory instruction time in the core subjects German, a foreign language, mathematics and natural sciences and by raising the graduation requirements. Based on administrative data covering all students, the empirical analysis is carried out by applying a difference-in-differences model. The results show that the reform increased university enrollment rates for both gender. With regard to choosing STEM as college major, we only find a robust positive effect for males.

JEL Classification: $\quad 121,123,128$

Keywords: high school curriculum, university educational decisions, reform evaluation, the choice of college major, STEM

Corresponding author:

Katja Görlitz

Freie Universität Berlin

Fachbereich Wirtschaftswissenschaft

Boltzmannstraße 20

14195 Berlin

Germany

E-mail: Katja.Goerlitz@fu-berlin.de

\footnotetext{
* The authors are grateful to Alexander Koch, Helena Skyt Nielsen and Marcus Tamm for helpful comments and suggestions. We further acknowledge comments and remarks from participants at the annual conference of the Royal Economic Society (2013), the Research Seminar in Economics at the FU Berlin, the DIW Applied Micro seminar, the Economics of Education Committee of the Verein für Socialpolitik (2014) and the Fuglesangs Alle Workshop (2014). All remaining errors are our own.
} 


\section{Introduction}

A highly skilled workforce is an important competitive advantage of industrialized countries. Consequently, in the US and in Europe increasing the number of college graduates is consistently on the political agenda (see e.g. "Make college a reality" Obama 2008 for the US and the Europe 2020 strategy). Especially for technological progress and scientific research, however, workers with expertise in mathematics and science are of particular importance. Hanushek and Kimko (2000) argue that a highquality education in mathematics and science is positively related to economic growth. Therefore, increasing the share of university graduates in the so-called "STEM" majors (science, technology, engineering or mathematics) is an explicit political aim worldwide. ${ }^{1}$ This paper analyzes the potential of redesigning the high school curriculum to achieve these aims. Focusing on the curriculum as a channel for influencing college enrollment and the choice of major is motivated by the manifold reforms intended to improve students' knowledge in mathematics, reading and writing that have already been carried out as in Germany or are currently being implemented in the US (see e.g. the "Common Core State Standards Initiative" and the "Next Generation Science Standards”) with the aim to prepare students better for college and careers.

From a theoretical perspective, the curriculum has the potential to affect college decisions. For example, it has been shown that increased instruction time leads to significant improvements in student achievement scores in some subjects (Lee and Barro 2001, Woessmann 2003, Marcotte 2007). To the extent that these improved skills increase labor productivity, educational choices of individuals could then be affected through higher wage expectations (Becker 1962, Beffy et al. 2012, Arcidiacono et al. 2012). Another avenue through which the curriculum could influence individuals' educational choices would be through a reduction of uncertainty about ability and preferences (Arcidiacono 2004, Altonji et al. 2012). Improved skills could also have an effect on the choice of college major because the students have a better prior knowledge of the subject and its challenges or because they are more self-confident to manage studying a STEM major successfully (Stinebrickner and Stinebrickner 2011).

\footnotetext{
${ }^{1}$ Some examples for "STEM" initiatives include: "COSEPUP” for the US, "Science and Innovation Investment Framework 2004-14” for the UK and "MINT Zukunft schaffen” for Germany.
} 
This paper presents evidence on the causal effects of a high school curriculum reform on university enrollment and the choice of college major. The effects are identified by exploiting exogenous variation from a reform that was introduced in one of the 16 German states. The curriculum of the last two high school years was changed significantly. Before the reform, high school students had a great degree of freedom to choose subjects on an advanced or basic level. After this freedom of choice was reduced, the average student experienced a significant increase in the level and the intensity in terms of weekly hours in the subjects German, a foreign language, mathematics and natural sciences. Furthermore, the graduation requirements increased as well. Based on administrative data covering the multitude of German students, we apply a difference-in-differences approach and, as a robustness check, the synthetic control group approach (Abadie et al. 2010). Heterogeneous effects by gender are estimated additionally. We find that the curriculum reform increased males' and females' likelihood to enroll at university and that males' STEM choice was positively affected.

There is a growing literature concerned with the effects of the high school curriculum. The majority of papers investigate the relationship between course choices in high school and wages (Altonji 1995, Levine and Zimmerman 1995, Dolton and Vignoles 2002, Rose and Betts 2004, Joensen and Nielsen 2009, Goodman 2012). A fewer number of papers also analyze how the curriculum is related to post-secondary educational attainment (Altonji 1995, Levine and Zimmerman 1995, Aughinbaugh 2012). Their results suggest a positive correlation between taking more advanced courses in high school (mainly in math) and post-secondary education. The literature concerned with the high school curriculum as a determinant of the choice of college major is even smaller. Levine and Zimmerman (1995) show a positive correlation between choosing additional high school math and science classes and choosing a technical college major. Broecke (2013) finds that increasing the learning intensity in physics and chemistry raises males' probability of taking-up studies in a scientific major. One shortcoming of most of these papers concerned with post-secondary educational decisions or college major choice is that they fail to have a causal 
interpretation. ${ }^{2}$ This is due to the difficulty of taking students' selection of basic and advanced courses adequately into account without having a source of exogenous variation.

This paper contributes to the literature in various ways. First, we estimate the causal effect of the high school curriculum on educational choice and college major choice by exploiting a state-level curriculum reform. We are only aware of three studies relying on exogenous reforms for the identification of the causal curriculum effects (Joensen and Nielsen 2009, Goodman 2012, Jia 2014) where the former two are concerned with the curriculum effects on wages. Second, analyzing the effect of the curriculum on educational decisions and the major choice (instead of wages) helps to expose the intermediary channels through which the curriculum can impact labor market outcomes later in life. Third, providing separate estimates of college major choices for males and females adds another piece to the occupational gender gap puzzle. For instance, there is evidence that differences in mathematical abilities can explain gender differences in college major choices (Paglin and Rufolo 1990, Turner and Bowen 1999, Joensen and Nielsen 2014). Part of this gap could stem from female self-selection out of mathematics and science classes if given a choice (Goldin et al. 2006).

The paper proceeds as follows. Section 2 describes the German schooling system and the curriculum reform in more detail. Section 3 introduces the data and the empirical methods. The results and sensitivity checks are contained in section 4 . Section 5 concludes the study.

\section{Institutional background and the reform}

\subsection{The German high school system}

In Germany, the 16 federal states decide upon their own education policy which is why they can differ considerably across states. The schooling system, in the time relevant for this study, is characterized by early tracking usually after fourth grade (at the age of ten), in some states also after sixth grade. The selection of school track is based on

\footnotetext{
${ }^{2}$ The only exception we are aware of is a recent paper by Jia (2014) who estimates the effect of increased math curriculum requirements on STEM using cross-state variation in the timing of increased curriculum requirements.
} 
ability and school achievement. The top-level school track is the high school (Gymnasium) which usually finishes with graduation after 13 years of schooling. Since the reform that is in the focus of this analysis was only introduced in academic high schools, the following descriptions refer to academic high schools in the pre-reform period. $^{3}$

The organization and the curriculum of the high school differ by grade. Until grade 11, every student has the same fixed curriculum and is taught within a class having the same peers each grade. Before the curriculum reform was introduced in 2002, a flexible course system was introduced in the last two years of high school (usually in grades 12 and 13) where students chose two advanced and several basic courses from a variety of subjects. Students' choices were restricted in as much as they had to choose subjects with a certain minimum amount of hours in each of the fields "languages and art", "social sciences" and "mathematics and natural sciences". Therefore, it was not possible to choose two natural sciences on the advanced level. Even though these restrictions existed, the flexible course system can be characterized by leaving a great deal of freedom of choice in course selection. This can be illustrated by using an example. While some students chose arts and French as their advanced subjects (dropping physics and chemistry), others specialized in mathematics and physics on an advanced level (dropping arts and French).

To obtain a high school diploma, the final high school exams at the end of 13th grade needs to be passed. Before the reform, the final exams were examined in the two advanced subjects and in one of the basic subjects in written tests and in another basic course in an oral test. However, in Baden-Württemberg students were required to pass the final exam in mathematics and German at least on the basic level. The high school grade point average (GPA) is calculated out of the grades obtained in the final high school exams in addition to all grades obtained in all subjects in the last two years of high school. The high school diploma is a necessary prerequisite for admission to German universities.

\footnotetext{
${ }^{3}$ More than 85 percent of German high school graduates have attended an academic high school that prepares students for university entrance in general. The remaining 15 percent attended a vocational high school that sets a more vocational focus in the curriculum.
} 
In contrast to the US system where students are allowed to try a number of courses before deciding on a major, German students choose one specialized college major when entering university. Even though some students change their major later on, this is only the case for less than 20 percent of the German students after the first semester (Konsortium Bildungsberichterstattung 2006). If the demand for study places exceeds the number of possible admissions in a major at a particular university, the GPA is the decisive factor for admission. However, this competition is only relevant for a small number of college majors at universities in popular cities. If the student is flexible as regards location and college major, university enrollment is always possible. Around 7 percent of the open slots are not allocated each year (Kultusministerkonferenz 2010).

\subsection{The curriculum reform}

At the end of 1999, the state of Baden-Württemberg implemented a reform that limited the freedom of choice in course selection during the last two years of academic high school. The first cohort affected by the reform entered grade 12 in 2002 and graduated from high school in 2004. In particular, the reform aimed at increasing broader general knowledge in the three core subjects German, a foreign language and mathematics. After the reform, participation in these subjects becomes mandatory on an advanced level for every student. Two additional subjects have to be chosen as advanced subjects. This increases the overall number of advanced subjects from two (prior to the reform) to five. However, the weekly hours in the advanced subjects was reduced by the reform from five to four hours. Another aim of the reform was to strengthen the natural sciences. After the reform, at least two subjects in the natural sciences had to be taken by every student. Furthermore, after the reform it is possible to choose two subjects in the natural sciences on the advanced level instead of only one as before.

These changes increased the total instruction time at school from a minimum of 26 hours to a minimum of 30 hours per week. Moreover, regulations about the final exams changed as well. After the reform, all three core subjects and another advanced subject are part of the final written exams. The fifth and sixth components are oral exams, one of them in either the fifth advanced subject or one of the basic subjects and the other one in one of the written exam subjects. In addition, the curriculum of the advanced subjects changed as well to accommodate the reduction in weekly hours from five to 
four. In particular, while the level and intensity of the main topics stays the same as in the pre-reform period, the number of specialized topics decreases. Table 1 summarizes the main changes of the curriculum.

Because of the reduction of weekly hours in advanced subjects from five to four, it is not a priori known how the reform changed the weekly hours in core subjects and natural sciences for the average student. Empirical results show that the average weekly hours rose by the reform in German by more than 15 percent (Neumann 2010), in English as a foreign language by 6 percent (Jonkmann et al. 2010) and in math by 7 percent (Nagy et al. 2010). In natural sciences, the weekly average hours increased the most, i.e., by 30 percent per week (Neumann and Nagy 2010). This is the case, inter alia, because more than half of the students choose a natural science as an advanced course after the reform, while only one fifth chose science as an advanced course before the reform.

\subsection{Previous results on the effects of the curriculum reform}

The curriculum reform was already evaluated with regard to its potential to increase student achievement. While the reform increased achievement scores in mathematics (Nagy et al. 2010), no significant achievement effects can be found in English as a foreign language (Jonkmann et al. 2010) or in natural sciences (Neumann and Nagy 2010). These findings are in line with the literature concerned with the effects of instruction time on achievement scores that find the instruction time to matter more for achievement in mathematics compared to other subjects like languages (Lee and Barro 2001, Woessmann 2003, Marcotte 2007).

The reform was also evaluated with regard to its effects on high school dropout rates (Görlitz and Gravert 2015). The evaluation results indicate that the probability to graduate from academic high school decreased for males in the years 2004 and 2005 and for females in the entire considered post-reform period (i.e. from 2004 to 2006). Particularly pronounced negative effects are found in 2004. Görlitz and Gravert (2015) interpret this result as a reform avoidance effect. The graduation cohort of 2004 had the

opportunity to avoid the reform by changing from an academic high school to a vocational high school because vocational high schools introduced the reform one year 
later and in a modified version that did not increase the degree of difficulty to such a large extent. In addition, a more pronounced effect of high school dropout for the 2004 cohort could also be due to the fact that the insecurity of students and teachers about the new curriculum requirements was larger compared to later years where some experiences had already been made. In conclusion, the effects in 2004 differed for males and females to a large extent from the other post-reform years which is why we do not consider effects in 2004 in this paper.

\section{Data and empirical method}

\subsection{Data and descriptive statistics}

The data used for the analysis is constructed by combining two administrative sources. The first data set is a register of all students enrolling at any German university that is provided by the Federal Statistical Office (Statistisches Bundesamt 2005 and 2008, GENESIS-online Datenbank). It is known for every student, when he/she has enrolled at university for the first time and which college major was chosen. Some further information is also contained like gender and the year and state of high school graduation. This analysis only considers high school graduates from academic high schools who have enrolled at university within two years after school graduation (as military or social service lasting for a year after high school was mandatory for men). The second data set contains annual information on the size of the age-specific cohort by year and state (Statistisches Bundesamt 2005 and 2008), in particular, the number of individuals that are of the same age as students during high school graduation (age 19). This source is also available separately by gender. Out of these two data sets, a repeated cross-sectional micro data is constructed for the time period 1999 to 2006. It contains one observation for every individual at age 19 by year and state indicating whether this individual has enrolled at university within two years after high school graduation (or not) and whether the individual has chosen STEM as major (or not).

Table 2 documents the share of individuals enrolling at university and choosing STEM as college major by treatment and control states ${ }^{4}$ and by the pre- and post-reform period.

\footnotetext{
${ }^{4}$ The control group is composed of German states who have not implemented educational reforms between 1999 and 2006. For further details see section 3.2.
} 
In Baden-Württemberg, the share of males enrolling at university is 16.1 percent before the reform and 17.3 percent afterwards. The corresponding shares for females are 18.7 percent before and 20.4 percent after the reform. In the control states, the share of males (females) with university enrollment is 16.4 (19.5) percent prior to the reform and 16.3 (20.0) in the post-reform period. With regard to the share of individuals choosing STEM as major, the shares developed in Baden-Württemberg between the pre- and post-reform period for males from 7.8 to 8.6 percent and for females from 4.4 to 4.9 percent. In the control states, the corresponding developments remained almost constant with 8 percent for males and slightly increased from 4.5 to 4.9 percent for females. Figure 1 depicts the developments of the share of students enrolling at university by treatment status and by the year of high school graduation. In the pre-reform period, the shares of males and females evolved similar in Baden-Württemberg and in the control states. For students choosing STEM as college major, Figure 2 shows that the shares also develop similar between treatment and control states before the reform was introduced.

\subsection{Estimation strategy}

To evaluate the effects of the curriculum reform on university enrollment and the choice of college major, we apply a difference-in-differences approach. The development of the outcome variables of interest in the pre- and post-period of the treatment state Baden-Württemberg is compared to the developments during the same time in the control group that consists of 12 German states. ${ }^{5}$ The following model is estimated separately by gender:

$Y_{i s t}=\alpha_{s}+\gamma_{t}+\beta D_{s t}+\varepsilon_{i s t}$

where $Y$ indicates two different outcomes measured at the individual level $i$ : First, a binary variable being 1 for enrolling at university (and zero otherwise) and, second, a binary variable being 1 for choosing STEM as college major (and zero otherwise). The year $t$ (with $t=99,00,01,02,03,05,06$ ) and the state $s$ refer to the year and state of high school graduation. $\alpha$ and $\gamma$ are state and year fixed effects, respectively. $D_{s t}$ represents a binary variable that is 1 in the post-reform years 2005 and 2006 in Baden-

\footnotetext{
${ }^{5}$ The control group incorporates all German states except for Hesse, Mecklenburg-Western Pomerania and Saxony-Anhalt because they implemented other school reforms in the time period under investigation.
} 
Württemberg and 0 otherwise. The year 2004 is excluded from the analysis because - as already mentioned -students avoided the reform by making use of the possibility to change schools, i.e. from academic to vocational schools, which was only possible in 2004 (Görlitz and Gravert 2015). The reform effects are, thus, contained in the coefficient $\beta$ that is provided separately for the two outcomes and for each gender. $\varepsilon_{i t}$ is an idiosyncratic error term.

Note that the regressions cover all individuals in the age-specific cohort. This means that we measure the reform effect on individuals' likelihood to enroll in university in relation to the entire age-specific cohort of all German residents in that age group (and not solely related to high school graduates). The same is true for choosing STEM as college major. This is important as the curriculum reform did also affect the share of academic high school students negatively (Görlitz and Gravert 2015). Restricting the regressions to academic high school graduates only would bias the results. If the weakest students (with no study intentions even in the absence of the reform) leave academic high school due to the reform, the share of individuals enrolling and choosing STEM would increase in the (selective) group of high school graduates even if the reform had no effect on the studying decision.

The regressions are estimated using the linear probability model. The standard errors are clustered at the state-year level to avoid problems with downward biased standard errors induced by common group errors (Moulton 1990). Since there is much debate about the inference in difference-in-differences models (Bertrand et al. 2004, Donald and Lang 2007), we apply alternative methods for calculating the standard errors. The standard errors are clustered at the state level and at the state-pre/post reform level which allow for temporal breaks in the dependence of the error term over time. Furthermore, clustering at the level of geographical areas allows for dependence over states and time (Bester et al. 2011). ${ }^{6}$ Last, the two-step model as suggested by Donald and Lang (2007) is applied as well.

The identification assumption in the difference-in-differences model is the common trend assumption. In particular, it is assumed that in the absence of the reform the

\footnotetext{
${ }^{6}$ The geographical clusters are defined by combining states in the Northwest, East, West, Southwest and Southeast. Inference is based on a t-distribution with four degrees of freedom.
} 
enrollment probability and the STEM choice would have evolved over time in BadenWürttemberg as in the control states. To check whether this assumption is likely to hold, a similar evolution of the variables of interest in the pre-reform period as was shown in Figure 1 and Figure 2 is evidence in favor of the validity of this assumption. It also looks as if there are no contemporaneous shocks in the pre-reform years. This suggestion is tested empirically by placebo-tests which are estimated by re-running the difference-in-differences regressions acting as if the treatment actually occurred in any of the years prior to the reform. Observing no statistical significant result in the placebo tests is evidence of no contemporaneous shocks. Furthermore, we test for the existence of linear time trends in the pre-reform period.

When applying a difference-in-differences estimator, one challenge is to define a proper control group. For reasons of checking the robustness, an alternative control group is defined using the synthetic control group approach (Abadie and Gardeazabal 2003, Abadie et al. 2010). The synthetic control group is defined as a weighted combination of the 12 German states that were already used for the difference-in-differences approach. The weights are chosen to minimize the difference in the outcome variable of interest between the control states and the treatment state in the pre-reform period. Since it is difficult to calculate standard errors when using the synthetic control group methods, the sensitivity analysis only relies on providing graphical evidence. For a more detailed explanation of the method see Appendix A-1.

One shortcoming with the data used for the empirical analysis is that it does not contain information on individual control variables. This would bias the estimation results, if the characteristics of high school students like socioeconomic or family background have changed during the time period under investigation. One counter-argument is that the analysis is based on a rather short time period that makes changes in such variables less likely. Another argument against this concern can be taken from the empirical literature. Becker et al. (2010) show that in Baden-Württemberg the high school graduation cohorts for the years 2002 and 2006 do not differ with respect to students' family background (e.g. parents’ education and economic status) or migration status. 


\section{Results and sensitivity analysis}

Table 3, columns 1 and 2 contains the reform effects for males' and females' probability to enroll at university. When clustering the standard errors at the state-year level, there are statistically significant positive effects of 1.3 percentage points for males and 1.2 percentage points for females. Regardless of how the standard errors are calculated, the reform effects always remain statistically significant. With regard to the reform effects on the likelihood to choose STEM as college major, Table 3, columns 3 and 4, documents the results for males and females. While the results for males indicate that the reform made them more like to choose a STEM major on a statistically significant level, this is not true for females. These conclusions even hold when calculating the standard errors with the alternative methods. Note that these results are estimated based on equation (1) which uses all pre-treatment years from 1999 to 2003 in the reference period. As the reform was announced in the end of 1999, we also estimated regressions using the pre-announcement year 1999 as reference. The size and significance of the effects is almost the same: There is a statistically significant enrollment effect of 1.4 percentage points for males and females alike and a statistically significant STEM effect for males of 1 percentage point and an insignificant STEM effect for females of 0.2 percentage points.

We find a positive effect of the curriculum reform on individuals' enrollment decision and on males' STEM choice. This is the case even though the reform had adverse effects on the probability to graduate from academic high schools (Görlitz and Gravert 2015). Taken these results together, the higher enrollment and STEM choice come off of a fewer number of academic high school graduates. This does not mean that the effects would even be higher in the absence of negative effects on high school decisions. If those leave high school due to the reform who would not study anyway (which we consider likely because of the results from Görlitz and Gravert 2015), the number of potential enrollees at university would be the same.

Table 4 contains the results of the placebo sensitivity tests for each of the pre-reform years 2000 to 2003. There are only a few statistically significant results that are small in terms of its size. However, these significant results do not remain statistically 
significant in every of the specifications based on alternative methods for inference. In conclusion, the placebo tests reveal that the results of this paper are not driven by contemporaneous shocks that also become apparent in other pre-reform years. To analyze the existence of anticipation effects, the placebo-tests were re-estimated using the pre-announcement year 1999 as the reference category. The corresponding results (not shown) indicate not a single of the results in the pre-reform years from 2000 to 2003 to differ statistically from 1999. This is true for both outcomes and both genders. Thus, we conclude that there is no evidence of anticipation effects. When considering time trends in the analysis to further check the robustness of the results, the trend can never be confirmed to be statistically significant at the 5 percent level. Re-estimating the reform effects including a time trend in equation (1) does not change the main conclusions either.

However, the results could also be driven by contemporaneous shocks that have occurred in any of the control states. This would mean that the estimated reform effect is not due to the reform, but actually due to other shocks having occurred in any of the control states. To shed some light on this issue, equation (1) (with state-year clustered standard errors) was re-estimated excluding one state at a time from the set of control states. Table 5 confirms the main conclusion for males and females alike. As another robustness check, we have excluded Saxony and Thuringia from the set of control states because they only require 12 years of high school. This did not alter our main conclusions.

The final robustness check estimates the reform effects based on the synthetic control group approach. As already mentioned, we only provide graphical evidence when using this method because of the difficulty to calculate standard errors. Figure 3 presents the graphical results for the enrollment probability. Figure 4 documents the results for the STEM choice. ${ }^{7}$ It is important to note, first of all, that the shares in Baden-Württemberg and those of the synthetic Baden-Württemberg are close to each other in the pre-reform period. This is descriptive evidence on the appropriateness of the synthetic control group approach. Concerning the results on university enrollment, it is clear from the figures that positive effects are visible in 2005 and 2006 for both sexes which reinforces

\footnotetext{
${ }^{7}$ The weights used to construct the synthetic control group are contained in Table 6.
} 
our previous findings. In terms of its size, the effects are somewhat smaller than the difference-in-differences results with a post-reform effect of approximately 1 percentage point for males and 0.8 percentage points for females (that is calculated by averaging the effects in 2005 and 2006). With regard to the STEM choice, the visual inspection of the graphs also suggests that the share of STEM students has increased compared to the pre-reform years. For males, the size of the effects is positive as in the difference-in-differences model, but again smaller in size with an average effect of 0.5 percentage points. For females, the reform effects estimated by the synthetic control group methods are also positive, but they are larger in size with 0.4 percentage points compared to the difference-in-differences model. As this latter result is at odds with our previous findings, we conclude that the result for females' STEM choice is not robust.

\section{Conclusion}

Many factors which determine the uptake of a university education and the choice of college major are outside of policy makers' scope (e.g. initial ability, demographic background or motivation). However, policy makers do have influence on institutional settings such as high school curriculum and minimum grading requirements. This paper evaluates the effect of a high school curriculum reform on the probability of university enrollment and the choice of college major. The reform reduced the freedom of choice in course selection which, in turn, increased mandatory instruction hours in German, a foreign language, math and science for the average student. Graduation requirements were also raised. The analysis relies on a quasi-experimental research design using exogenous variation in the introduction of the curriculum reform by time and states.

The results indicate that the reform increased students' willingness to enroll at university for males and females alike. The reform effect of university enrollment can be assessed as meaningful with 1.3 and 1.2 percentage points for females and males, respectively. As a comparison, Heller (1997) shows that for every 100 dollar increase in tuition fees university enrollment decreases by 0.5 to 1 percentage points. Similarly, Dynarski (2002) found that an increase in financial aid of 1000 US dollars increased the enrollment probability by 4 percentage points. Effect sizes for financial aid in Germany are similar to those of the US (Steiner and Wrohlich 2012). Arguably, a curriculum reform is more cost-effective in the long run. 
Concerning individuals' likelihood to choose STEM as college major, the results suggest a positive and robust effect for males. The finding that the curriculum reform affected males' STEM choice more clearly compared to females’ could be explained by recent findings on the gender gap in major choice. Zafar (2013) shows that the reason for differences in occupational choice is because males and females differ in their preferences. It is not that females have doubts about their abilities. While the reform has probably the potential to change beliefs about abilities (e.g. through its impact on student achievement), it is less likely to change individuals' tastes or preferences.

In sum, our results suggest that curricula reforms have the potential to affect postsecondary school decisions. It should be noted, however, that further increases in the degree of difficulty of the curriculum can also have diminishing or even negative effects. For instance, further increases might even keep those high school students from enrolling who have the abilities to study successfully by increasing the effort costs. The optimal degree of difficulty of the curriculum can only be determined based on a large number of evaluation results.

One shortcoming of our analysis is that we only look at initial choices instead of performance variables (i.e. achieving a university degree and STEM diploma). However, our results suggest individuals' choices to study and their choice of college major actually being influenced by the curriculum requirements. When modelling these choices theoretically, the curriculum should be considered as an influencing factor. One avenue for future empirical research would be to explain through which channels individual's choices are affected. For example, it could be improved skills as was shown for mathematics (Trautwein et al. 2010) or more optimistic beliefs about graduating from university successfully (Montmarquette et al. 2002). 


\section{References}

Abadie, A. and J. Gardeazabal (2003), The Economic Costs of Conflict: A Case Study of the Basque Country. The American Economic Review, 93 (1), 113-132.

Abadie, A., A. Diamond and J. Hainmueller (2010), Synthetic Control Methods for Comparative Case Studies: Estimating the Effect of California's Tobacco Control Program. Journal of the American Statistical Association, 105 (490), 493-505.

Altonji, J. G. (1995), The Effects of High School Curriculum on Education and Labor Market Outcomes. The Journal of Human Resources, 30 (3), 409-438.

Altonji, J., E. Blom and C. Meghir (2012), Heterogeneity in Human Capital Investments: High School Curriculum, College Major, and Careers. Annual Review of Economics, 4 (1), 185-223.

Arcidiacono, P. (2004), Ability sorting and the returns to college major. Journal of Econometrics, 121 (1-2), 343-375.

Arcidiacono, P., V. J. Hotz and S. Kang (2012), Modeling college major choices using elicited measures of expectations and counterfactuals. Journal of Econometrics, 166 (1), 3-16.

Aughinbaugh, A. (2012), The effects of high school math curriculum on university attendance: Evidence from the NLSY97. Economics of Education Review, 31 (6), 861870.

Becker, G. S. (1962), Investment in human capital: A theoretical analysis. Journal of Political Economy, 70 (5), 9-49.

Becker, M., K. Maaz and M. Neumann (2010), Schulbiografien, familiärer Hintergrund und kognitive Eingangsvoraussetzungen im Kohortenvergleich, 37-90. In: Trautwein, U., M. Neumann, G. Nagy, O. Lüdtke and K. Maaz (eds.), Schulleistungen von 
Abiturienten. Die neu geordnete gymnasiale Oberstufe auf dem Prüfstand. VS Verlag, Wiesbaden.

Beffy, M., D. Fougère and A. Maurel (2012), Choosing the Field of Study in Postsecondary Education: Do Expected Earnings Matter? The Review of Economics and Statistics, 94 (1), 334-347.

Bertrand, M., E. Duflo and S. Mullainathan (2004), How Much Should We Trust Differences-in-Differences Estimates? The Quarterly Journal of Economics, 119 (1), 249-275.

Bester, C. A., T. G. Conley and C. B. Hansen (2011), Inference with dependent data using cluster covariance estimators. Journal of Econometrics, 165, 137-151.

Blackmore, A. E. and S. A. Low (1984), Sex Differences in Occupational Selection: The Case of College Majors. The Review of Economics and Statistics, 66 (1), 157-163.

Broecke, S. (2013), Does offering more science at school increase the supply of scientists? Education Economics, 21 (4), 325-342.

COSEPUP (Committee on Science, Engineering, and Public Policy) (2007), Rising Above the Gathering Storm: Energizing and Employing America for a Brighter Economic Future. The National Academies Press.

Dolton, P.J. and A. Vignoles (2002), Is a broader curriculum better? Economics of Education Review, 21 (5), 415-429.

Donald, S. G. and K. Lang (2007), Inference with Difference-in-Differences and Other Panel Data. The Review of Economics and Statistics, 89 (2), 221-233.

Dynarski, S. M. (2003), Does Aid Matter? Measuring the Effect of Student Aid on University Attendance and Completion. The American Economic Review, 93 (1), 279288. 
Görlitz, K. and C. Gravert (2015), The effects of increasing the standards of the high school curriculum on school dropout. Economics Discussion Paper of the Freie Universität Berlin 2015/1.

Goldin, C., L. F. Katz and I. Kuziemko (2006), The Homecoming of the American University Women: The Reversal of the University Gender Gap. Journal of Economic Perspectives, 20 (4), 133-156.

Goodman, J. (2012), The labor of division: Returns to compulsory math coursework. HKS Faculty Research Working Paper Series RWP 12-032.

Hanushek, E. A. and D. Kimko (2000), Schooling, Labor-Force Quality, and the Growth of Nations. The American Economic Review, 90 (5), 1184-1208.

Heller, D. E. (1997), Student Price Response in Higher Education: An Update to Leslie and Brinkman. The Journal of Higher Education, 68 (6), 624-659.

Jia, Ning (2014), Do Stricter High School Math Requirements Raise College STEM Attainment? Mimeo.

Joensen, J. S. and H. S. Nielsen (2009), Is there a Causal Effect of High School Math on Labor Market Outcomes? Journal of Human Resources, 44 (1), 171-198.

Joensen, J. S. and H. S. Nielsen (2014), Mathematics and Gender: Heterogeneity in Causes and Consequences. Economic Journal (forthcoming).

Jonkmann, K, U. Trautwein, G. Nagy and O. Köller (2010), Fremdsprachenkenntnisse in Englisch vor und nach der Neuordnung der gymnasialen Oberstufe in BadenWürttemberg, 37-90. In: Trautwein, U., M. Neumann, G. Nagy, O. Lüdtke and K. Maaz (eds.), Schulleistungen von Abiturienten. Die neu geordnete gymnasiale Oberstufe auf dem Prüfstand. VS Verlag, Wiesbaden.

Konsortium Bildungsberichterstattung (2006), Bildung in Deutschland. W. Bertelsmann Verlag, Bielefeld. 
Lee, J.-W. and R. J. Barro (2001), School Quality in a Cross-Section of Countries. Economica, 68 (272), 465-488.

Levine, P. B. and D. J. Zimmerman (1995), The Benefit of Additional High-School Math and Science Classes for Young Men and Women. Journal of Business and Economic Statistics, 13 (2), 137-149.

Marcotte, D. E. (2007), Schooling and Test Scores: A Mother-Natural Experiment. Economics of Education Review, 26 (5), 629-640.

Montmarquette, C., K. Cannings and S. Mahseredjian (2002), How do young people choose university majors? Economics of Education Review, 21 (6), 543-556.

Moulton, B. R. (1990). An Illustration of a Pitfall in Estimating the Effects of Aggregate Variables on Micro Units. The Review of Economics and Statistics, 72 (2), 334-338.

Nagy, G., M. Neumann, U. Trautwein and O. Lüdtke (2010), Voruniversitäre Mathematikleistungen vor und nach der Neuordnung der gymnasialen Oberstufe in Baden-Württemberg, 37-90. In: Trautwein, U., M. Neumann, G. Nagy, O. Lüdtke and K. Maaz (eds.), Schulleistungen von Abiturienten. Die neu geordnete gymnasiale Oberstufe auf dem Prüfstand. VS Verlag, Wiesbaden.

Neumann, M. (2010), Innovation oder Restauration- Die (Rück-?)Reform der gymnasialen Oberstufe in Baden-Württemberg, 37-90. In: Trautwein, U., M. Neumann, G. Nagy, O. Lüdtke and K. Maaz (eds.), Schulleistungen von Abiturienten. Die neu geordnete gymnasiale Oberstufe auf dem Prüfstand. VS Verlag, Wiesbaden.

Neumann, M. and G. Nagy (2010), Mathematische und naturwissenschaftliche Grundbildung vor und nach der Neuordnung der gymnasialen Oberstufe in BadenWürttemberg, 37-90. In: Trautwein, U., M. Neumann, G. Nagy, O. Lüdtke and K. Maaz (eds.), Schulleistungen von Abiturienten. Die neu geordnete gymnasiale Oberstufe auf dem Prüfstand. VS Verlag, Wiesbaden. 
Paglin, M. and A. M. Rufolo (1990), Heterogeneous Human Capital, Occupational Choice, and Male-Female Earnings Differences. Journal of Labor Economics, 8 (1), 123-144.

Rose, H. and J. R. Betts (2004), The Effect of High School Courses on Earnings. The Review of Economics and Statistics, 86 (2), 497-513.

Statistisches Bundesamt (2005), Nichtmonetäre hochschulstatistische Kennzahlen, 1980-2003, Fachserie 11 Reihe 4.3.1, Wiesbaden.

Statistisches Bundesamt (2008), Nichtmonetäre hochschulstatistische Kennzahlen, 1980-2007, Fachserie 11 Reihe 4.3.1, Wiesbaden.

Steiner, V. and K. Wrohlich (2012), Financial Student Aid and Enrollment in Higher Education: New Evidence from Germany. The Scandinavian Journal of Economics, 114 (1), 124-147.

Stinebrickner, T. R. and R. Stinebrickner (2011), Math or Science? Using Longitudinal Expectations Data to Examine the Process of Choosing a College Major. NBER Working Papers 16869.

Turner, S. E. and W. G. Bowen (1999), Choice of Major: The Changing (Unchanging) Gender Gap. Industrial and Labor Relations Review, 52 (2), 289-331.

Woessman, L. (2003), Schooling Resources, Educational Institutions and Student Performance: the International Evidence. Oxford Bulletin of Economics and Statistics, 65 (2), 117-170.

Zafar, B. (2013), College Major Choice and the Gender Gap. The Journal of Human Resources 48(3), 545-595. 
Figure 1. Trend in the share of high school graduates enrolling at university related to the age-specific cohort by gender, in percent

Panel A: Males

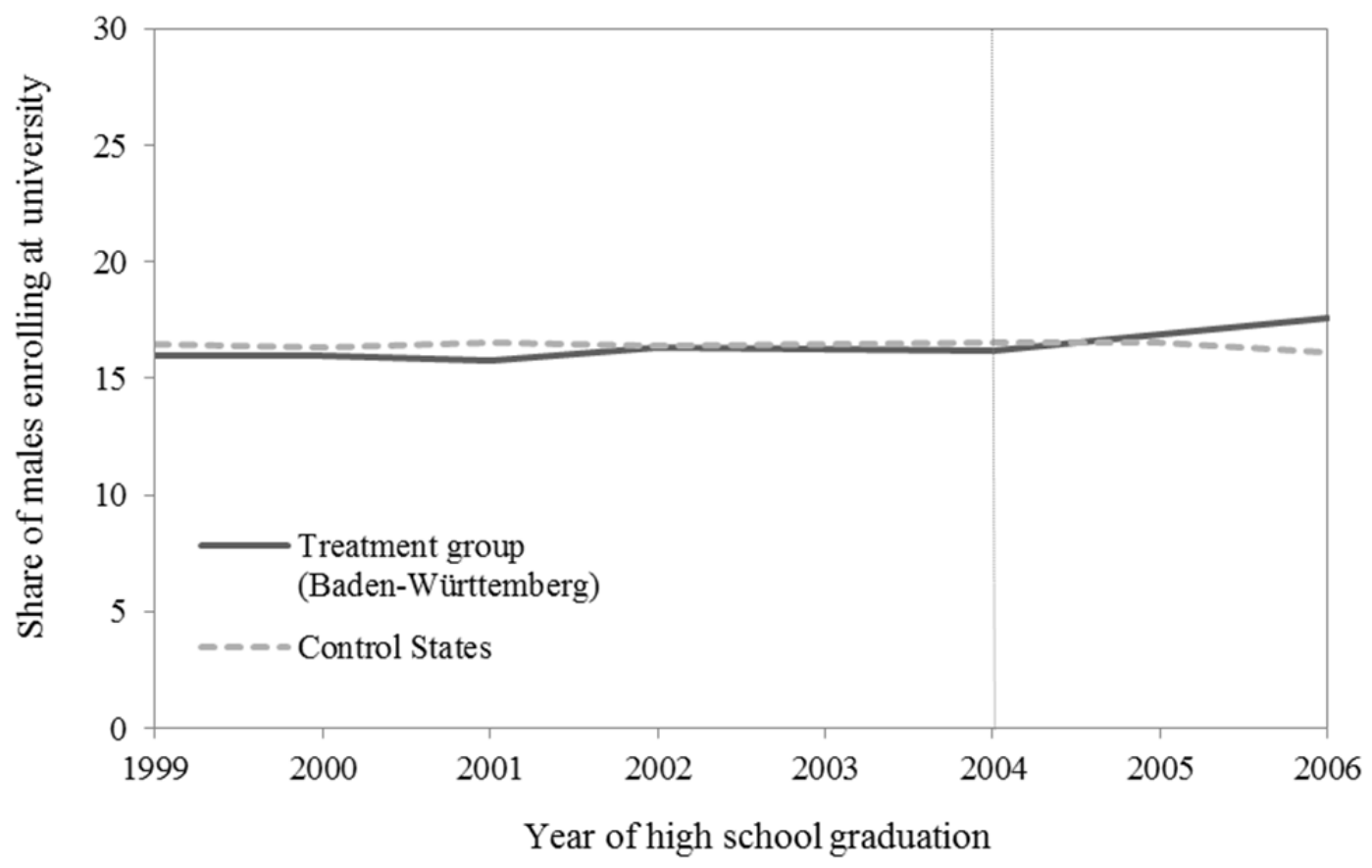

Panel B: Females

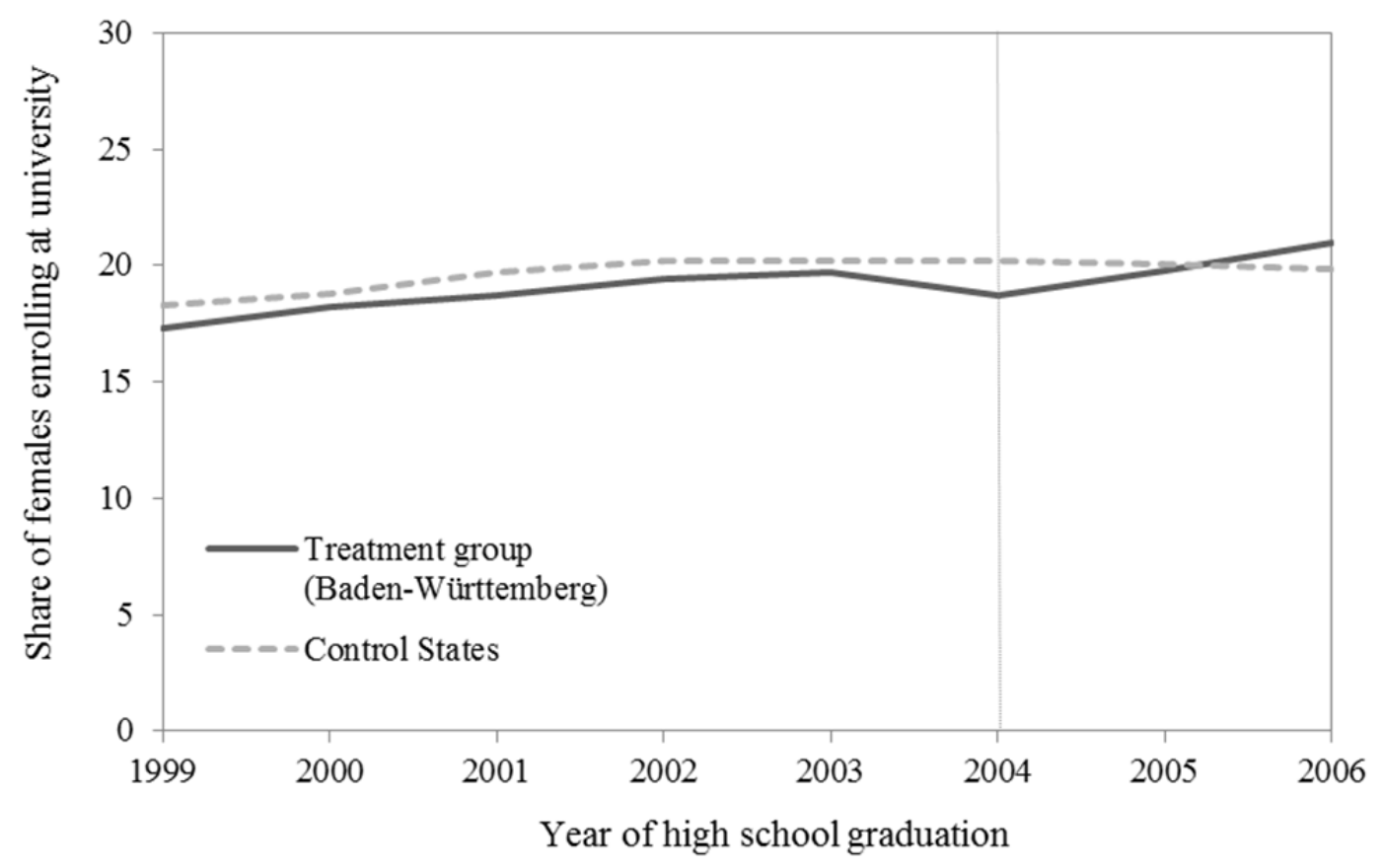


Figure 2. Trend in the share of high school graduates choosing STEM as major related to the age-specific cohort by gender, in percent

Panel A: Males

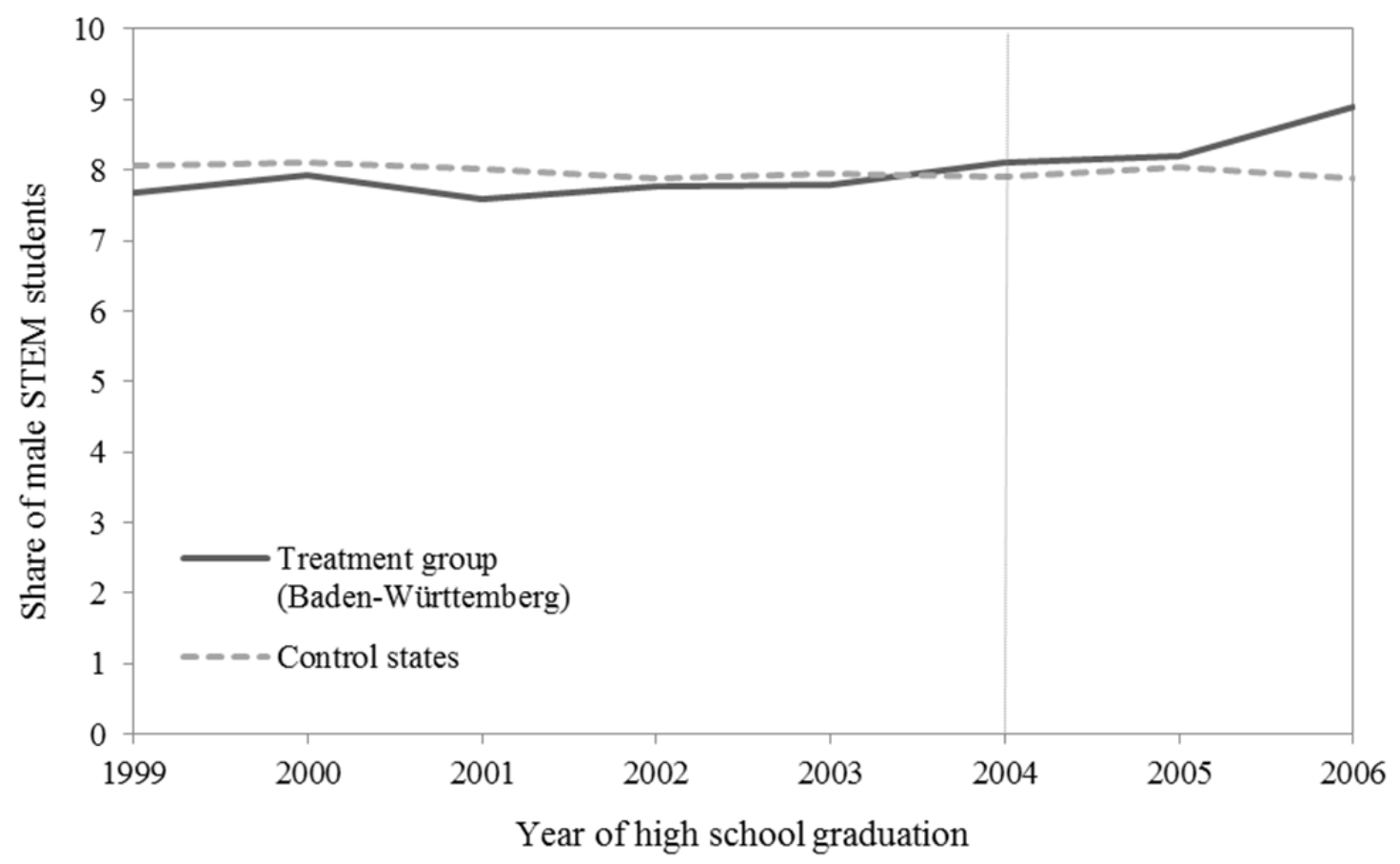

Panel B: Females

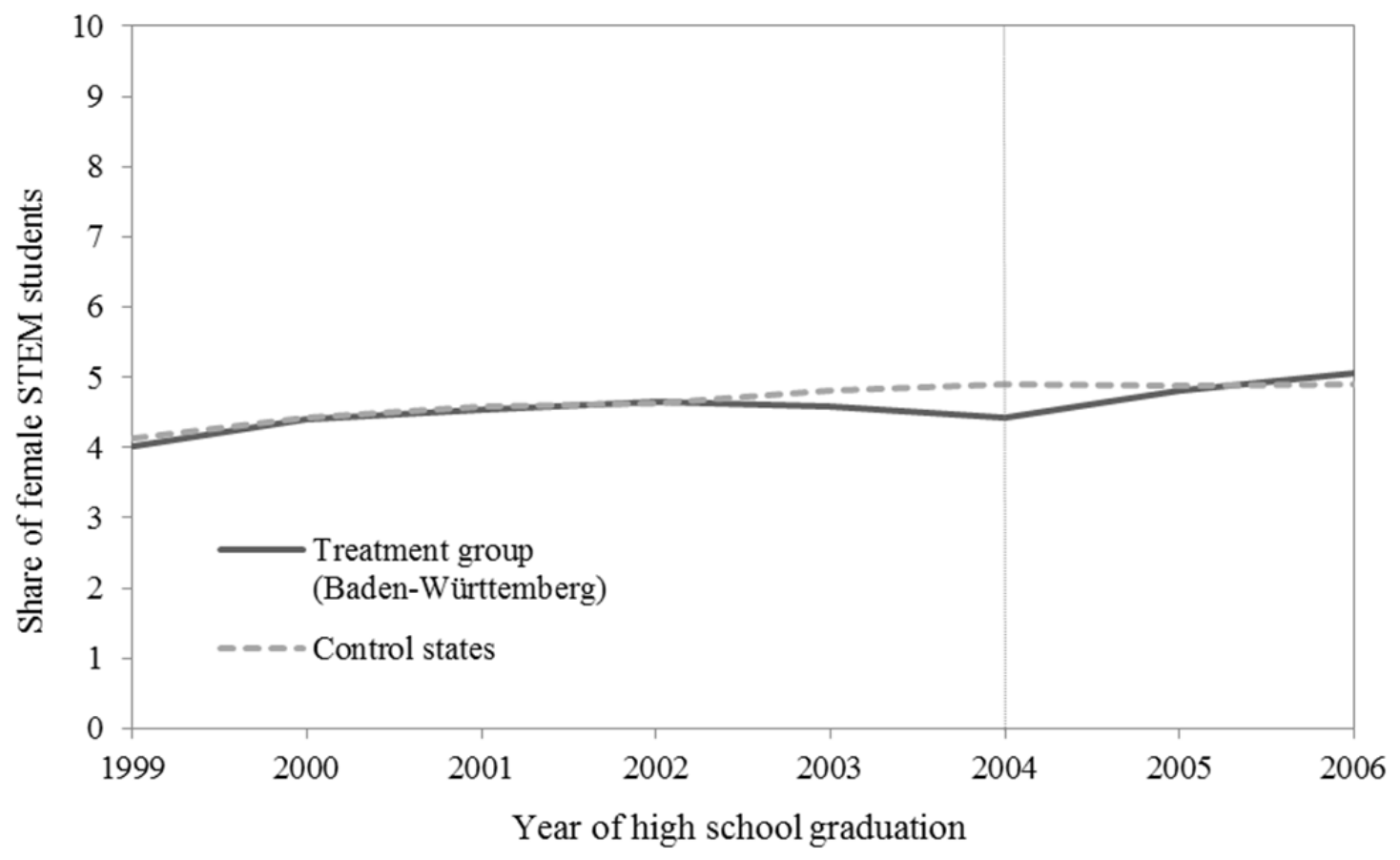


Figure 3. Gap in the share of high school graduates enrolling at university in BadenWürttemberg and in the synthetic Baden-Württemberg by gender, in percent

Panel A: Males

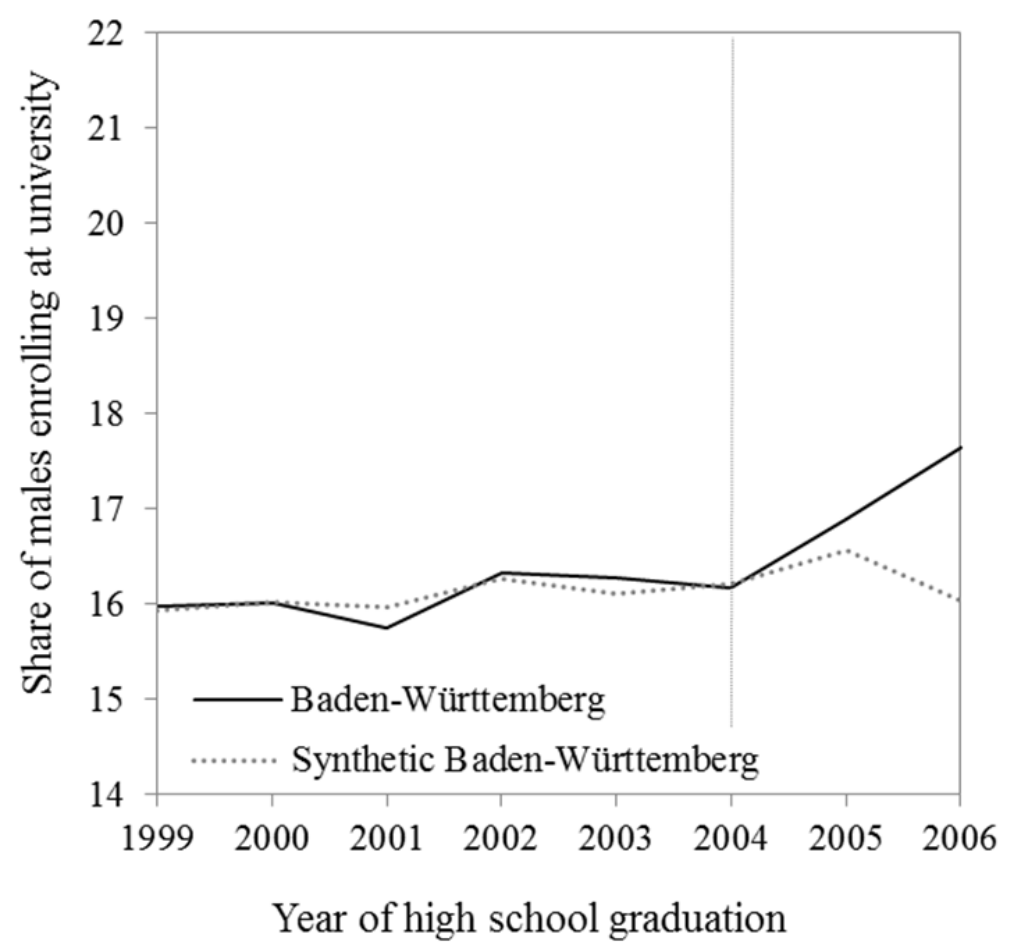

Panel B: Females

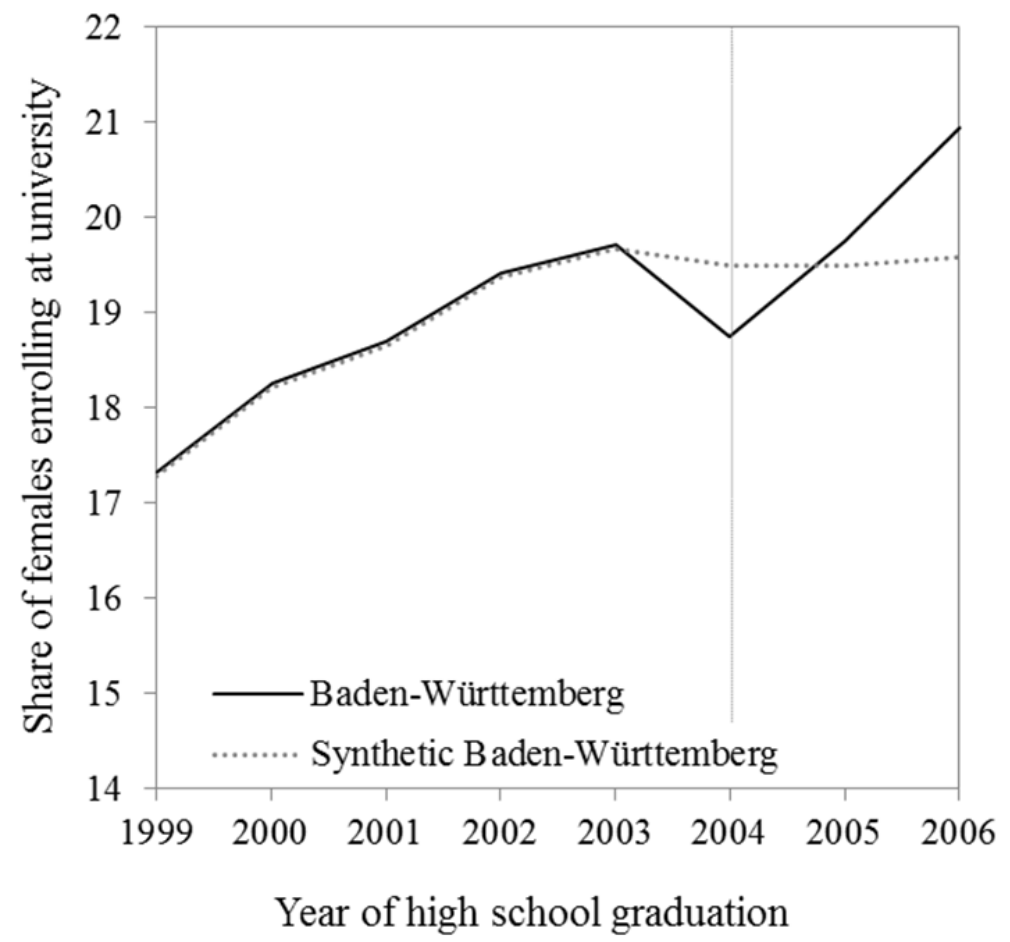


Figure 4. Gap in the share of high school graduates choosing STEM as major in BadenWürttemberg and in the synthetic Baden-Württemberg by gender, in percent

Panel A: Males

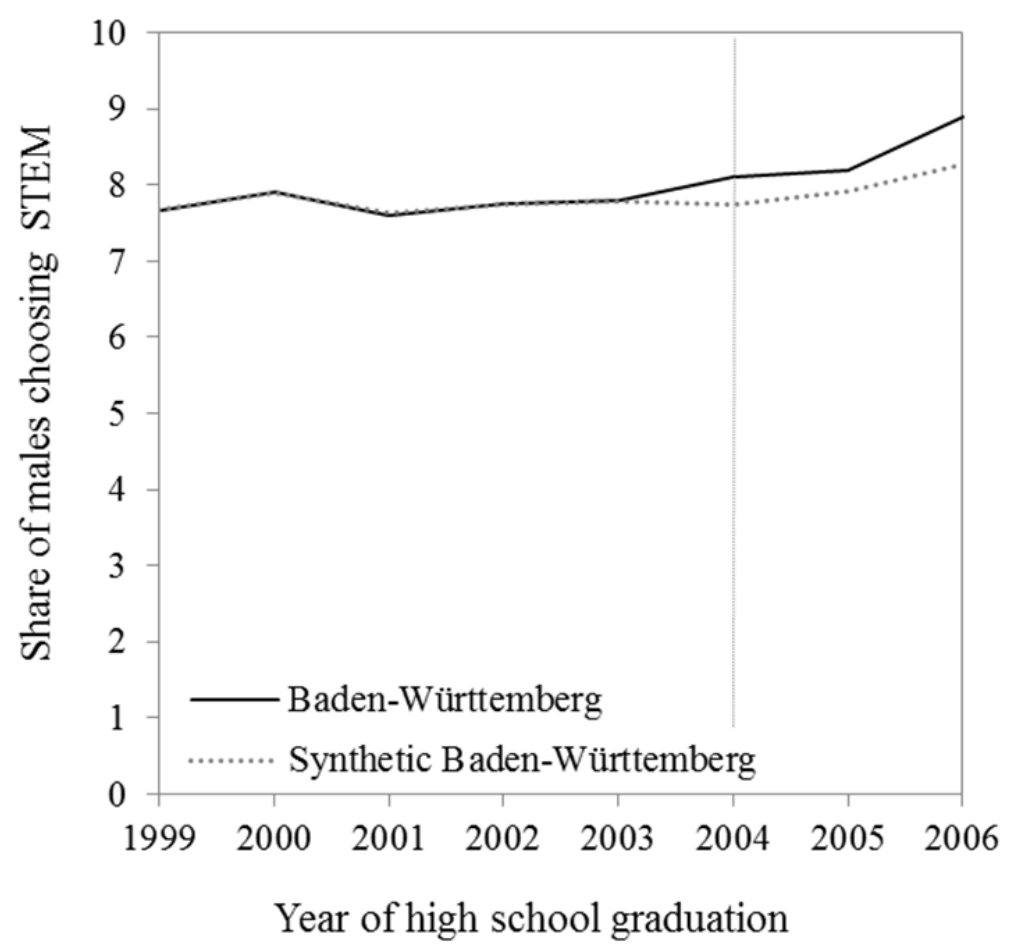

Panel B: Females

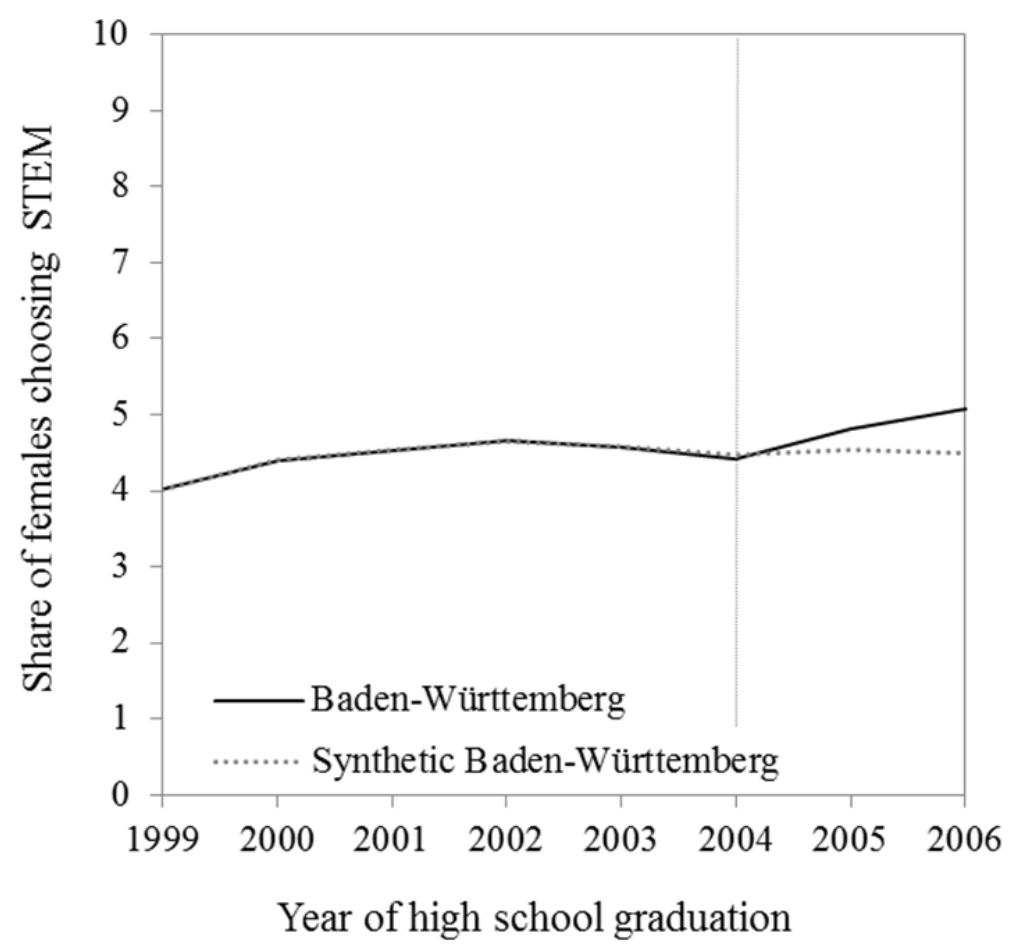


Table 1. Major changes in the curriculum of Baden-Württemberg

\begin{tabular}{|c|c|}
\hline Before the reform & After the reform \\
\hline Minimum instruction of 26 hours a week & Minimum instruction of 30 hours a week \\
\hline 2 advanced courses for 5 hours each week & 5 advanced courses for 4 hours each week \\
\hline $\begin{array}{l}\text { Mathematics, German and a foreign } \\
\text { language on a basic level for } 3 \text { hours/ week } \\
\text { (if not chosen as an advanced course) }\end{array}$ & $\begin{array}{l}\text { Mathematics, German and a foreign } \\
\text { language on an advanced level for } 4 \text { hours/ } \\
\text { week }\end{array}$ \\
\hline Only one natural science mandatory & Two natural sciences mandatory \\
\hline $\begin{array}{l}\text { Only one natural science on an advanced } \\
\text { level possible }\end{array}$ & $\begin{array}{l}\text { Two natural sciences on an advanced level } \\
\text { possible }\end{array}$ \\
\hline $\begin{array}{l}\text { Three written final exams and one oral } \\
\text { exam }\end{array}$ & $\begin{array}{l}\text { Four written final exams and two oral } \\
\text { exams }\end{array}$ \\
\hline
\end{tabular}

Table 2. Descriptive statistics

\begin{tabular}{|c|c|c|c|c|c|}
\hline & \multirow[b]{2}{*}{$\begin{array}{l}\text { Obser- } \\
\text { vations }\end{array}$} & \multicolumn{2}{|c|}{ Baden-Württemberg } & \multicolumn{2}{|c|}{ Control states } \\
\hline & & $\begin{array}{l}\text { Mean } \\
\text { before } \\
\text { reform }\end{array}$ & $\begin{array}{c}\text { Mean } \\
\text { after } \\
\text { reform }\end{array}$ & $\begin{array}{l}\text { Mean } \\
\text { before } \\
\text { reform }\end{array}$ & $\begin{array}{l}\text { Mean } \\
\text { after the } \\
\text { reform }\end{array}$ \\
\hline \multicolumn{6}{|l|}{ Males } \\
\hline $\begin{array}{l}\text { Probabiltiy of enrolling } \\
\text { at university }\end{array}$ & $2,910,089$ & 0.161 & 0.173 & 0.164 & 0.163 \\
\hline Probability of choosing & & & & & \\
\hline STEM as major & $2,910,089$ & 0.078 & 0.086 & 0.080 & 0.080 \\
\hline \multicolumn{6}{|l|}{ Females } \\
\hline $\begin{array}{l}\text { Probabiltiy of enrolling } \\
\text { at university }\end{array}$ & $2,789,401$ & 0.187 & 0.204 & 0.195 & 0.200 \\
\hline Probability of choosing & & & & & \\
\hline STEM as major & $2,789,401$ & 0.044 & 0.049 & 0.045 & 0.049 \\
\hline
\end{tabular}


Table 3. The effects of the curriculum reform on individuals' choice to enroll at university and to choose STEM as major

\begin{tabular}{lccccc}
\hline $\begin{array}{l}\text { Calculation } \\
\text { of the stan- } \\
\text { dard errors }\end{array}$ & $\begin{array}{c}\text { Dependent variable: Probability } \\
\text { to enroll at university }\end{array}$ & & \multicolumn{2}{c}{$\begin{array}{c}\text { Dependent variable: Probability } \\
\text { to choose STEM as major }\end{array}$} \\
\cline { 2 - 3 } \cline { 5 - 6 } & $\begin{array}{c}\text { Males } \\
(1)\end{array}$ & $\begin{array}{c}\text { Females } \\
(2)\end{array}$ & & $\begin{array}{c}\text { Males } \\
(3)\end{array}$ & $\begin{array}{c}\text { Females } \\
(4)\end{array}$ \\
\hline State-year cluster & $0.0131 * * *$ & $0.0116^{* *}$ & & $0.0084 * * *$ & 0.0014 \\
& $(0.0044)$ & $(0.0047)$ & & $(0.0031)$ & $(0.0011)$ \\
State cluster & $0.0131 * * *$ & $0.0116 * * *$ & & $0.0084 * * *$ & 0.0014 \\
& $(0.0032)$ & $(0.0024)$ & & $(0.0020)$ & $(0.0012)$ \\
State-pre/post & $0.0131 * * *$ & $0.0116 * * *$ & & $0.0084 * * *$ & 0.0014 \\
cluster & $(0.0024)$ & $(0.0018)$ & & $(0.0015)$ & $(0.0009)$ \\
Five region cluster & $0.0131 * *$ & $0.0116 * * *$ & & $0.0084 * *$ & 0.0014 \\
(4 df) & $(0.0037)$ & $(0.0020)$ & & $(0.0022)$ & $(0.0013)$ \\
Two-step procedure & $0.0131 * * *$ & $0.0116 * *$ & & $0.0084 * * *$ & 0.0014 \\
& $(0.0039)$ & $(0.0050)$ & & $(0.0024)$ & $(0.0018)$ \\
Observations & $2,910,089$ & $2,789,401$ & & $2,910,089$ & $2,789,401$ \\
\hline
\end{tabular}

Notes: The dependent variable in column 1 and 2 is a binary variable that indicates enrolling into university (1) or not (0). The dependent variable in column 3 and 4 is a binary variable that indicates choosing STEM as college major (1) or not (0). The table contains only the result for the reform effects $(\beta)$ estimated by equation (1) by Ordinary Least Squares. The standard errors are shown in parentheses. The rows represent the results for alternative calculations of the standard errors. That is clustering at the state-year level (91 clusters), clustering at the state level (13 clusters), clustering at the five region level (5 clusters) and using the two-step procedure.

$* * p<0.05$
$* * * p<0.01$ 
Table 4. Test for placebo effects

\begin{tabular}{lccccc}
\hline $\begin{array}{l}\text { Placebo } \\
\text { reform } \\
\text { in year }\end{array}$ & $\begin{array}{c}\text { Dependent variable: Probability } \\
\text { to enroll at university }\end{array}$ & & \multicolumn{2}{c}{$\begin{array}{c}\text { Dependent variable: Probability } \\
\text { to choose STEM as major }\end{array}$} \\
\cline { 2 - 3 } \cline { 5 - 6 } & $\begin{array}{c}\text { Males } \\
(1)\end{array}$ & $\begin{array}{c}\text { Females } \\
(2)\end{array}$ & & $\begin{array}{c}\text { Males } \\
(3)\end{array}$ & $\begin{array}{c}\text { Females } \\
(4)\end{array}$ \\
\hline 2000 & 0.0017 & 0.0043 & & 0.0020 & 0.0008 \\
& $(0.0037)$ & $(0.0029)$ & & $(0.0021)$ & $(0.0011)$ \\
2001 & -0.0038 & -0.0024 & & -0.0014 & 0.00002 \\
& $(0.0021)$ & $(0.0030)$ & & $(0.0015)$ & $(0.0010)$ \\
2002 & $0.0046 * *$ & -0.00001 & & 0.0020 & 0.0008 \\
& $(0.0018)$ & $(0.0022)$ & & $(0.0012)$ & $(0.0010)$ \\
2003 & 0.0023 & 0.0032 & & 0.0011 & $-0.0020 * *$ \\
& $(0.0017)$ & $(0.0020)$ & & $(0.0011)$ & $(0.0008)$ \\
& & & & \\
Observations & $2,910,089$ & $2,789,401$ & & $2,910,089$ & $2,789,401$ \\
\hline
\end{tabular}

Notes: The dependent variable in column 1 and 2 is a binary variable that indicates enrolling in university (1) or not (0). The dependent variable in column 3 and 4 is a binary variable that indicates choosing STEM as college major (1) or not (0). Equation (1) is estimated with the difference that the treatment year was set on the placebo years 2000, 2001, 2002 and 2003. The standard errors that are shown in parentheses are clustered at the year-state level.

$* * p<0.05$

$* * * p<0.01$ 
Table 5. Results when excluding one state at a time from the control states

\begin{tabular}{|c|c|c|c|c|}
\hline \multirow[t]{2}{*}{$\begin{array}{l}\text { Excluded } \\
\text { state }\end{array}$} & \multicolumn{2}{|c|}{$\begin{array}{c}\text { Dependent variable: Probability to } \\
\text { enroll at university } \\
\end{array}$} & \multicolumn{2}{|c|}{$\begin{array}{c}\text { Dependent variable: Probability to } \\
\text { choose STEM as major }\end{array}$} \\
\hline & $\begin{array}{c}\text { Males } \\
(1)\end{array}$ & $\begin{array}{c}\text { Females } \\
(2)\end{array}$ & $\begin{array}{c}\text { Males } \\
(3)\end{array}$ & $\begin{array}{c}\text { Females } \\
(4)\end{array}$ \\
\hline Bavaria & $\begin{array}{l}0.0137 * * * \\
(0.0049)\end{array}$ & $\begin{array}{l}0.0125 * * \\
(0.0052)\end{array}$ & $\begin{array}{l}0.0095 * * * \\
(0.0034)\end{array}$ & $\begin{array}{r}0.0018 \\
(0.0014)\end{array}$ \\
\hline Berlin & $\begin{array}{l}0.0133 * * * \\
(0.0046)\end{array}$ & $\begin{array}{l}0.0105 * * \\
(0.0046)\end{array}$ & $\begin{array}{l}0.0085 * * * \\
(0.0032)\end{array}$ & $\begin{array}{r}0.0010 \\
(0.0011)\end{array}$ \\
\hline Brandenburg & $\begin{array}{l}0.0132 * * * \\
(0.0046)\end{array}$ & $\begin{array}{l}0.0117^{* *} \\
(0.0048)\end{array}$ & $\begin{array}{l}0.0083 * * * \\
(0.0031)\end{array}$ & $\begin{array}{r}0.0012 \\
(0.0011)\end{array}$ \\
\hline Bremen & $\begin{array}{l}0.0131 * * * \\
(0.0044)\end{array}$ & $\begin{array}{l}0.0116 * * \\
(0.0047)\end{array}$ & $\begin{array}{l}0.0084 * * * \\
(0.0031)\end{array}$ & $\begin{array}{r}0.0013 \\
(0.0011)\end{array}$ \\
\hline Hamburg & $\begin{array}{l}0.0138 * * * \\
(0.0044)\end{array}$ & $\begin{array}{l}0.0115 * * \\
(0.0049)\end{array}$ & $\begin{array}{l}0.0085 * * * \\
(0.0031)\end{array}$ & $\begin{array}{r}0.0012 \\
(0.0012)\end{array}$ \\
\hline $\begin{array}{l}\text { Lower } \\
\text { Saxony }\end{array}$ & $\begin{array}{l}0.0129 * * * \\
(0.0045)\end{array}$ & $\begin{array}{l}0.0105 * * \\
(0.0043)\end{array}$ & $\begin{array}{l}0.0083 \text { ** } \\
(0.0032)\end{array}$ & $\begin{array}{r}0.0008 \\
(0.0010)\end{array}$ \\
\hline $\begin{array}{l}\text { North Rhine- } \\
\text { Westphalia }\end{array}$ & $\begin{array}{l}0.0093 * * * \\
(0.0028)\end{array}$ & $\begin{array}{l}0.0108 * * * \\
(0.0038)\end{array}$ & $\begin{array}{l}0.0061 \text { *** } \\
(0.0017)\end{array}$ & $\begin{array}{l}0.0024 \text { ** } \\
(0.0011)\end{array}$ \\
\hline $\begin{array}{l}\text { Rhineland- } \\
\text { Palatine }\end{array}$ & $\begin{array}{l}0.0135 * * * \\
(0.0044)\end{array}$ & $\begin{array}{l}0.0130 * * * \\
(0.0048)\end{array}$ & $\begin{array}{l}0.0085 \text { *** } \\
(0.0031)\end{array}$ & $\begin{array}{r}0.0018 \\
(0.0011)\end{array}$ \\
\hline Saarland & $\begin{array}{l}0.0131 * * * \\
(0.0045)\end{array}$ & $\begin{array}{l}0.0119 \text { ** } \\
(0.0048)\end{array}$ & $\begin{array}{l}0.0083 * * * \\
(0.0031)\end{array}$ & $\begin{array}{r}0.0014 \\
(0.0011)\end{array}$ \\
\hline Saxony & $\begin{array}{l}0.0136 * * * \\
(0.0043)\end{array}$ & $\begin{array}{l}0.0110 * * \\
(0.0048)\end{array}$ & $\begin{array}{l}0.0086 * * * \\
(0.0030)\end{array}$ & $\begin{array}{r}0.0012 \\
(0.0011)\end{array}$ \\
\hline $\begin{array}{l}\text { Schleswig- } \\
\text { Holstein }\end{array}$ & $\begin{array}{l}0.0132 * * * \\
(0.0045)\end{array}$ & $\begin{array}{l}0.0118 \text { ** } \\
(0.0047)\end{array}$ & $\begin{array}{l}0.0085 * * * \\
(0.0031)\end{array}$ & $\begin{array}{r}0.0013 \\
(0.0011)\end{array}$ \\
\hline Thuringia & $\begin{array}{l}0.0140 \text { *** } \\
(0.0044)\end{array}$ & $\begin{array}{l}0.0118 * * \\
(0.0047)\end{array}$ & $\begin{array}{l}0.0087 \text { *** } \\
(0.0031)\end{array}$ & $\begin{array}{r}0.0011 \\
(0.0011)\end{array}$ \\
\hline
\end{tabular}

Notes: The results are estimated based on equation (1) with the difference that in each regression one state is excluded when defining the control group. For further notes on the estimation, see the notes in Table 3. The standard errors that are shown in parentheses are clustered at the year-state level.

$* * p<0.05$

$* * * p<0.01$ 
Table 6. Synthetic control group weights for different outcomes

\begin{tabular}{|c|c|c|c|c|}
\hline \multirow[t]{2}{*}{$\begin{array}{l}\text { Federal } \\
\text { State }\end{array}$} & \multicolumn{2}{|c|}{$\begin{array}{l}\text { University } \\
\text { enrollment }\end{array}$} & \multicolumn{2}{|c|}{$\begin{array}{c}\text { STEM as } \\
\text { college major }\end{array}$} \\
\hline & $\begin{array}{c}\text { Males } \\
(1) \\
\end{array}$ & $\begin{array}{c}\text { Females } \\
(2) \\
\end{array}$ & $\begin{array}{c}\text { Males } \\
(3) \\
\end{array}$ & $\begin{array}{c}\text { Females } \\
(4) \\
\end{array}$ \\
\hline Bavaria & 0 & 0.24 & 0.50 & 0.02 \\
\hline Berlin & 0 & 0.01 & 0 & 0.24 \\
\hline Brandenburg & 0.13 & 0.05 & 0.15 & 0.04 \\
\hline Bremen & 0 & 0.01 & 0 & 0.04 \\
\hline Hamburg & 0.10 & 0.04 & 0.08 & 0.06 \\
\hline Lower Saxony & 0.33 & 0.21 & 0 & 0.05 \\
\hline North Rhine-Westphalia & 0.23 & 0.04 & 0 & 0.03 \\
\hline Rhineland-Palatinate & 0 & 0.17 & 0 & 0.02 \\
\hline Saarland & 0 & 0.03 & 0 & 0.03 \\
\hline Saxony & 0 & 0.04 & 0.02 & 0.03 \\
\hline Schleswig-Holstein & 0 & 0.07 & 0 & 0.43 \\
\hline Thuringia & 0.21 & 0.09 & 0.24 & 0.01 \\
\hline
\end{tabular}




\section{Appendix}

\section{A-1. The synthetic control group}

In the synthetic control group approach (Abadie and Gardeazabal 2003, Abadie et al. 2010), the treatment state is compared to a weighted combination of other states. The weights are chosen to minimize the difference in the outcome variable of interest between the control states and the treatment state in the pre-reform period. Instead of using the individual data, the synthetic control group method is run on aggregated data. The data is created by aggregating the original data based on the student characteristics by year and state of high school graduation and by gender. The estimation proceeds in two steps. First, there are $J$ possible control regions (12 other German states) and each of them is given a weight out of $W=\left(\mathrm{w}_{1}, \ldots, \mathrm{w}_{\mathrm{J}}\right)$ to create a synthetic BadenWürttemberg. All weights are non-negative and restricted to one to prevent extrapolation.

$\mathrm{w}_{\mathrm{j}}(\mathrm{j}=1, \ldots, \mathrm{J})$ stands for the weight of region $j$ in the synthetic Baden-Württemberg. $\mathrm{Z}_{1}$ is a ( $\left.8 \times 1\right)$ vector which contains the means of the outcome variables for 1999 until 2006 in Baden-Württemberg. $\mathrm{Z}_{0}$ is a $(8 \mathrm{x} \mathrm{J})$ matrix which contains the means of the outcome variables for the other German states. The vector $W^{*}$ defines the combination of control regions which best resembles the distribution of the means of the outcome variables in Baden-Württemberg before the reform in 2004. It is constructed by: $W^{*}=\min \left(Z_{1}-Z_{0} W\right)$. Second, in order to find the development of STEM students in the synthetic Baden-Württemberg, the vector of the real mean values of the control states $Z_{0}$ is multiplied with the vector of the minimized weights: $Z_{1}^{*}=Z_{0} W^{*}$. The only control variables for the regression are the values for the years before the reform. After the year of the reform the synthetic Baden-Württemberg shows how the trend would have developed had there not been a reform. $Z_{1}^{*}$ and $Z_{1}$ can then be compared before and after the reform to calculate the reform effects by differencing the fractions each year and averaging those differences over the number of periods. 